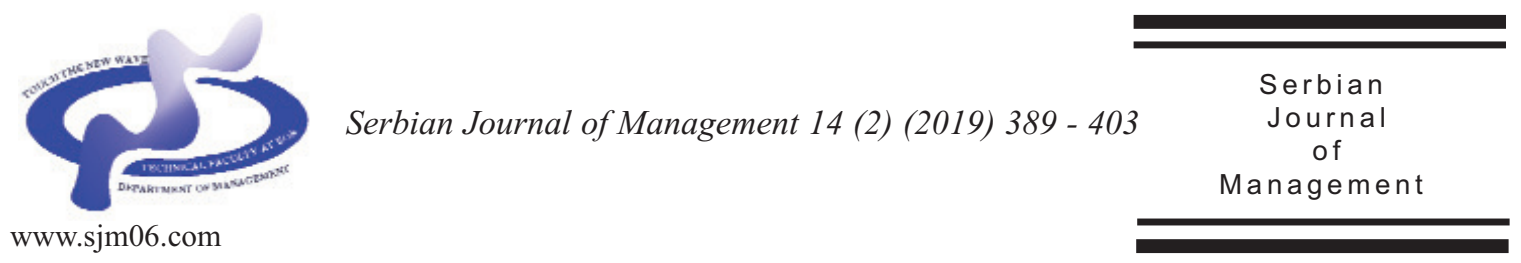

\title{
DISCRIMINATORY MODELS' ADAPTATION IN SMALL AND MEDIUM SIZED HEALTH CARE ENTITIES
}

\author{
Aleksandra Szewieczek* and Bartłomiej Lisicki \\ University of Economics in Katowice, The Faculty of Finance and Insurance, Department \\ of Accounting, 40-287 Katowice, ul. 1 Maja 50, Poland
}

(Received 22 August 2019; accepted 28 September 2019)

\begin{abstract}
The article presents the utilization of discriminatory analysis in small and medium sized hospitals. The discriminatory models are used to estimate the probability of researched hospitals bankruptcy. The financial distress is tested with two popular models, one foreign (the Altman Z"Score Model) and one domestic (the Mączyńska Model). The authors also construct their own model, adapted to the specification of medical activity. The results indicate that the author's model is much more suitable for the small and medium sized hospitals, as the rate of prediction is highest. It may indicate that in the health care sector, particularly in small and medium sized companies, different phenomena occur, which affect these companies' financial distress. Despite this, this study indicates that the proposed model is one of the useful tools for their evaluation, especially when combined with other financial as well as non-financial tools. Finally, it was possible to verify the hypothesis that it is possible to create a discriminatory model dedicated to SMEs hospitals, which results are more accurate than using different, not adjusted to health care sector specifics, discriminatory models.
\end{abstract}

Keywords: financial distress, discriminatory analysis, health care, management, accounting, SME

\section{INTRODUCTION}

The legal conditions of the functioning of health care entities limit the possibility of bankruptcy a part of them. In Poland, public entities are not subject to bankruptcy law (Bankruptcy Law, 2019; Bem et al., 2019), while commercial entities are fully covered. Similar situations appear in other countries, although often with a functional background. Non-profit hospitals also tend to find alternative strategies to avoid formal bankruptcy proceedings for liquidation or reorganization (Langabeer, 2008). This does

\footnotetext{
* Corresponding author: aleksandra.szewieczek@ue.katowice.pl
}

DOI: $10.5937 /$ sjm14-22902 
not limit the utilization of bankruptcy prediction models (discriminatory models) in the current and strategic management of healthcare entities. It even extends their field of application. Bankruptcy can be understood in various ways, including insolvency, payment disability or bankruptcy. Discriminatory models may be used to support managers in foreseeing the near-term future and to create appropriate strategies in advance (Langabeer, 2008).

Health care entities are a specific and very important group in each state, but at the same time very difficult to manage. These units are largely financed from public funds, where spending rules are particularly restrictive. At the same time, these entities are characterized by constant financial problems (Landry et al. 2009). Financial instability in the indicated entities is probably caused by the system of their financing. At the same time, financial effects of instability are covered by the public sector (e.g. subsidies, co-financing) as well as private investors who do not meet the assumed rate of return on capital engaged in private medical investments. In addition, the non-financial effects of these instabilities affect society.

A number of initiatives are taken to supervise the indicated area. The arguments concerning changes in the financing rules and organization of the whole health care system are not discussed in the article, as the main aim is different. The authors focus on the micro level, individual medical entities. In these units a number of control activities are carried out, which are dependent on, inter alia, the ownership structure and organizational and legal form. Some of them take the form of specialized activities, targeted at selected companies. Such activities include internal control processes in the public sector (Szewieczek, 2015), as well as ranking supervised entities through a selected set of financial ratios (The Ordinance, 2017). Another example is different mechanism of debt restructuring (Kaur \& Srivastava, 2017). Summarizing, the health care sector is subjected to attempts to adapt solutions used in other industries. However, their effectiveness should be further examined in detail. Discriminatory Models can be an example of such adaptation.

The concept of discriminatory models, or even some parts of it (e.g. financial indicators analysis, financial distress analysis) are used for the prediction of the future financial position of hospitals (Bazzoli \& Cleverley, 1994). Such research is the subject of a growing interest of researchers; however the number of studies is still low. These studies are in the major part selective. For example, selected hospitals are examined because of their size (Augurzky \& Schmitz, 2000; Kopiński \& Porębski, 2015), also in comparison with other countries (Siedlecki et al., 2015), or because of their different types, for example acute care hospitals (Langabeer et al., 2018), teaching hospitals (Langabeer, 2006), rural hospitals (Holmes et al., 2017; Bem at al., 2019), as well as the ownership structure (Horwitz, 2005). At the same time, general models commonly used for the study of financial distress are widely used. Meanwhile, as Kitowski (2013) and other researches emphasize (Mączyńska \& Zawadzki, 2006; Rogowski, 2008; Tomczak \& Radosiński, 2017), these models do not possess the value of universality. Iwanowicz (2018) showed, on the basis of Polish enterprises from three industries - service, production and trade, that the transferability of Altman models to the conditions of the Polish economy and the sector universality of models cannot be 
positively confirmed. Even Altman (2005), pointed out, that different models should be built and tested derived from the country's own dissimilarity. Moreover, what is important, discriminatory models are based on financial data, completely neglecting nonfinancial aspects (Wardzińska, 2012). That's why these models should not be the only assessment tool. However, this does not diminish their potential and analytical value. In the health care sector, it seems to be particularly important as the financial condition of the whole branch is weak. Bearing it in mind attempts are being made to create bankruptcy prediction models, adapted to specific sectors. One can indicate shipping enterprises (Juszczyk \& Balina, 2009), health care entities (Kopiński \& Porębski, 2015), and many others. The size of the activity is also taken into account (Keasey et al., 2014), although we have not been able to find studies on discriminatory models in SMEs hospitals.

Therefore, adaptation of discriminatory models takes place in the industry as well as in the system dimension, defining the general structure of such models, including, for example, the number of analyzed financial indicators.

The above result indicated that the main aim of the article is the construction of the author's model of financial distress prediction dedicated to the specificity of medical activity. The presented model will be verified in terms of its suitability for the risk assessment of the stability of functioning of selected medical entities from the group of small and medium-sized enterprises. The results of the tests will also be compared with the results obtained by using two selected models: Z "-score Altman and Mączyńska.

The paper is presented in 3 sections. The following section provides a theoretical background of discriminatory model development, as well as synthetic presentation of selected models that will be used in the research section. The next section presents the methodology used, sample description and research results. The last two parts of the paper consist of discussion and conclusions.

\section{THEORETICAL FRAMEWORK AND HYPOTHESES}

Discriminatory models are tools for an entity economic condition assessment. There are used to predict the nearest financial situation of a company, which is connected to financial distress, bankruptcy, insolvency and other similar problems (Stein, 2007). Financial distress can be defined as having financial difficulties. It can be explained from two main points of view. From the perspective of theoretical analysis, when it has different degrees e.g. mild (temporary cash flow difficulty), serious (business failure or bankruptcy) and many various forms between the two extremes. From the perspective of empirical research, which means that an entity meets some situation that caused an enterprise's financial difficulty (Sun et al., 2013). A general rule for a discriminatory model is that they consist of a number of financial indicators that are accompanied with their weights. The numbers of financial indicators are generally under 10 (average 4 or 5). The ratios weights reflected to their importance in assessing the company probability of financial distress. The list of indicators and their weights allows calculation of the final sum, which reflects to the limits marked by the model's author and finally allows assessing the 
probability of the company's bankruptcy.

There are many discriminatory models that were proposed in the literature and practice. Many of them were constructed under the American economy, as well as for manufacturing enterprises. There are also a lot of attempts to adjust these models or build a new one that is appropriate for emerging economies or specific sectors.

Discriminatory methods constitute a kind of synthesis of the ratio analysis. These methods are concerned with assessing the financial instability of the entity soon (bankruptcy, liquidation, others). Based on previous research (Kitowski, 2013; Iwanowicz, 2018) pointing out the lack of model's universality in different industries and the lack of model's transferability between different countries, the authors select two common models, one domestic and one foreign. These models are used to conduct a comparative analysis of the results obtained:

1. The Altman's Model Z"-score Model.

2. The Mączyńska’s Model.

2.1. The Altman Z"-score model (Altman \& Narayan, 1997; Altman, 2005; Altman \& Hotchkiss, 2006; Altman 2013; Altman, 2018)

The presented model had been revised, and now it is adjusted for emerging markets (EMS). Although the prior model was created for a perfect market economy conditions, based on USA companies financial statements there were attempts to change the proposed weight measures (Merkevicius et al., 2006). This model has been most widely used for predicting financial distress (Baranoff et al., 2000;
Grice \& Ingram, 2001; Canbas et al., 2005; Holmes et al., 2017). The equation presented below was adjusted to the non-US corporates. In the emerging market model, the author added a constant term of +3.25 to standardize the scores with a score of Zero (0) equated to a D (default) rated bond (Altman \& Hotchkiss, 2006; Altman, 2013). This results in comparability with assessment made by ranking scores agencies. The model uses the equation (1) for overall index:

$$
\mathrm{Z}=6.56 \mathrm{X}_{1}+3.26 \mathrm{X}_{2}+6.72 \mathrm{X}_{3}+1.05 \mathrm{X}_{4}+3.25
$$

where:

$X_{1}$ - Working capital/Total assets

$\mathrm{X}_{2}$ - Retained earnings/Total assets

$\mathrm{X}_{3}$ - Operating Income (Earnings before interests and income taxes-EBIT)/Total assets

$\mathrm{X}_{4}$ - Book value of equity/Total liabilities

The criteria of scores assessment are:

$Z \leq 5.25$ Entity is in imminent danger of bankruptcy

$\mathrm{Z}>5.25$ Entity is in very good financial condition

\subsection{The Mączyńska's Model (Mączyńska, 1994)}

The presented model has been prepared for the study of polish enterprises from the construction industry. Qualified by its author for simplified methods of assessing the economic and financial condition of enterprises. Based on six basic ratios:

$\mathrm{X}_{1}$ - (Gross profit + amortization)/Total liabilities

$\mathrm{X}_{2}$ - Total assets/Total liabilities 
$\mathrm{X}_{3}$ - Assets profitability $=$ Gross profit (Earnings before taxes)//Total assets

$\mathrm{X}_{4}$ - Gross profit (Earnings before taxes)/Sales revenue $\mathrm{X}_{5}$ - Inventory turnover $=$ Inventory/Sales revenue

$\mathrm{X}_{6}$ - Total assets turnover $=$ Sales revenue/Total assets

The model uses the equation (2) for overall index:

$\mathrm{M}=1.5 \mathrm{X}_{1}+0.08 \mathrm{X}_{2}+10 \mathrm{X}_{3}+5 \mathrm{X}_{4}+0.3 \mathrm{X}_{5}+0.1 \mathrm{X}_{6}(2)$

The criteria of scores assessment are:

$\mathrm{M}<0$ Entity is weak and the probability of bankruptcy is high

$0<\mathrm{M}<1$ Entity is rather weak, but free from bankruptcy risk

$1 \leq \mathrm{M} \leq 2$ Entity is in good financial condition

$M \geq 2$ Entity is in very good financial condition

In accordance with the research goal, and the literature review, authors developed the hypothesis that was the subject of detailed research composition:

Table 1. Sample characteristics
Hypothesis: It is possible to create a discriminate model dedicated to SMEs hospitals, where results are more accurate than using different, not adjusted to health care sector specifics, discriminatory models.

Based on a set of selected financial indicators and financial data from the research group of SME hospitals the authors build also their own original model and compare its results to two comparable models. The procedures and results are presented in the next two sections.

\section{METHODOLOGY}

The first aim of the research was to verify the suitability of other, selected early warning methods to predict the bankruptcy of enterprises. They were the two models described earlier: The Altman Z"'-score model (designed for emerging markets) and The Mączyńska's Model (one of the most popular discriminatory models created in Poland). However, as mentioned above, the main purpose of this article was to create a discriminatory model, adapted for forecasting the risk of bankruptcy of SME entities from the health care sector.

\begin{tabular}{|c|c|}
\hline Hospital characteristics & Additional information \\
\hline $\begin{array}{c}\text { Sample size: } 70 \\
\text { Prior sample size: } 474 \\
\text { Status of the firm: Active and bankrupts } \\
\text { Number of employees: }<250\end{array}$ & $\begin{array}{l}\text { Due to the base limitations it is not possible to collect data } \\
\text { before the year } 2014\end{array}$ \\
\hline $\begin{array}{c}\text { Sum of assets: }<43 \text { million euro } \\
\text { Net turnover: }<50 \text { million euro } \\
\text { Data accessible for the year: } 2014-2017 \\
\end{array}$ & $\begin{array}{l}\text { The sample consists of hospitals that presented important } \\
\text { financial data for the entire period (2014-2017) }\end{array}$ \\
\hline $\begin{array}{c}\text { Sector NAICS } \\
\text { Hospitals: 622 } \\
\text { Sector PKD 2007(Polish Classification of } \\
\text { Activities) } \\
\text { Hospital activity (86.10.Z) }\end{array}$ & $\begin{array}{l}\text { In first step NAICS classification was used, second step } \\
\text { was connected with exclusion of medical practices and } \\
\text { similar activities. }\end{array}$ \\
\hline
\end{tabular}


The research sample consists of 70 small and medium-sized non-profit hospitals. The financial data was obtained from the EMIS Intelligence base. Detailed information about the sample is presented in Table 1. All presented financial data is expressed in thousands of Polish zlotys (thousand PLN).

Using the discriminatory functions for above mentioned models' authors calculated values of function for selected small and medium-sized hospitals. Among these entities 50 of them have continued their business activity while 20 were liquidated (during the years 2014-2017). The difference between the number of operating and bankrupt enterprises was caused by the limited availability of financial results of hospitals, which have ceased. Moreover, this proportion is meant to reproduce a significant predominance of entities operating in comparison to these bankruptcies. However, such disparities in the construction of discriminatory models are found in research of another authors
(Gołębiowski \& Żywno, 2009; PtakChmielewska \& Kuleta, 2018). Financial data for the operating entities were collected from their financial statements for the year 2017. In relation to bankrupt enterprises the data was used for the last full financial year which was preceded by bankruptcy.

The second stage of the research concerned construction of the model created by authors, used to forecasting the bankruptcy of entities from the health care sector classified as small and medium-sized enterprises.

To construct this model a set of 21 basic financial indicators were used (Table 2). This group consists of ratios included in:

1. The Altman and Mączyńska models.

2. Selected universal polish literature.

3. The Ordinance (2017), used to evaluate the financial standing of public hospitals in Poland.

4. Indicated by authors as very important for the medical activity.

At the same time the indicators that do not

\section{Table 2. Financial ratios used to financial distress model construction}

\begin{tabular}{lll}
\hline & Indicator (Explanatory variable $-\mathbf{X}$ ) & \multicolumn{1}{c}{ Formula } \\
\hline 1 & Current ratio (CR) & Current assets/Current liabilities \\
2 & Working capital ratio & Working capital/total assets \\
3 & Quick ratio (QR) & (Current assets-stocks)/Current liabilities \\
4 & Total debt ratio & Total liabilities/Total assets \\
5 & Debt to equity ratio & Total liabilities/Equity \\
6 & Current liabilities ratio & Current liabilities/Total assets \\
7 & Current receivables to current liabilities ratio & Current receivables/Current liabilities \\
8 & Days sales outstanding (DSO) & (Receivables average x 365)/Sales revenue \\
9 & Liabilities turnover (in days) & (Payables average x 365)/Sales revenue \\
10 & Total assets turnover (TAT) & Sales revenue/assets average \\
11 & Fixed assets turnover & Sales revenue/fixed assets average \\
12 & Labour costs in operating costs ratio & Labour cost/Operating costs \\
13 & Operating rent of sales & Earnings before interests and taxes/Sales revenue \\
14 & Rent of assets (ROA) & Net profit/total assets \\
15 & Operating rent of asses & Earnings before interests and taxes/Total assets \\
16 & Service of a debt ratio & (Net profit + amortization)/Total liabilities \\
17 & Share of equity in total assets & Equity/total assets \\
18 & Current liabilities in total debt ratio & Current liabilities/total liabilities \\
19 & Coverage ratio for non-current assets & Fixed assets/long term liabilities \\
20 & Rent of sales (ROS), Net profit margin & Net profit/sales revenue \\
21 & Rent of equity (ROE) & Net profit/equity \\
\hline Source: based on (Mączyńska 1994; Altman, 2005; Altman \& Hotchkiss, 2006; Bednarski, 2007; The Ordinance, 2017) &
\end{tabular}


present significant values in health care entities were not included, due to the specific nature of their operations (e.g. inventory turnover ratio), similar indicators included in above mentioned sources, as well as indicators whose calculation was not possible on the basis of financial data available in the database.

Based on the stepwise regression and least-squares method it was decided to verify which of proposed indicators (model explanatory variables) would allow in the most accurate way to predict the bankruptcy of the studied hospitals. In order to construct an appropriate discriminatory model, it was necessary to process a quantitative quantification of the qualitative explanatory variable, which was the status of the conducted business activity. In this part, authors assigned a value 0 of the discriminatory function for the bankrupt and 1 for the operating entities (Juszczyk \& Balina, 2009).

The first step in the research was the elimination of highly correlated variables. The limit assumed the value of the Pearson's correlation coefficient $(R)$ at the level of 0.7 . Then, using the method of least squares, the linear regression coefficients of the function were calculated. One of the last parts was gradual rejection of those variables whose statistical significance was the lowest. It continued until all variables in the regression model were significant at least at $p$-value $<0.05$. After the assignment the indicators to the models and calculation of their regression coefficient were set critical value of the discriminatory function. If a model value for the entities would be lower than critical value, we could think that entity would go bankrupt in the near future.

\footnotetext{
${ }^{1}$ Due to the lack of possibility to obtain information about the profit distribution in indicated enterprises, instead of retained earnings a net profit was used.
}

\section{RESULTS}

In the first stage the authors used the Altman Z' -score model and the Mączyńska's model to assess the utilization of these models in the studied group of companies. A comparison of forecasts of these models is presented in Tables 3 and 4.

Effectiveness of bankruptcy forecasting in the group of the selected 70 enterprises in the Altman's ${ }^{1}$ model was $62.86 \%$ and in the Mączyńska's model was only $54.29 \%$. Considering the effectiveness of these models in both groups of companies being tested, it is extremely important for bankrupt entities. Therefore, authors checked the accuracy of the prediction for the insolvent companies. For the Altman's model it was $60 \%$ and for Mączyńska's model 65\%. It is worth emphasizing that the company's qualification criteria (in the Mączyńka's model) are quite imprecise. They indicate a "neutral zone" between the discriminatory function values 0 and 2 , which can interfere with the correctness of forecasts.

The above results indicate the existence of insufficient predictive power of these bankruptcy models for enterprises from the health care sector. The situation was an inspiration for the authors to create a new discriminatory model dedicated to medical entities.

In the process of the new model construction, the first step was the removal of variables (from the above-mentioned 21 indicators) highly correlated with each other. Based on that variables $\mathrm{X}_{3}, \mathrm{X}_{4}, \mathrm{X}_{11}, \mathrm{X}_{15}$, $X_{16}, X_{17}, X_{20}$ and $X_{21}$, which show strong interdependence, were excluded from further calculations. From the remaining 13 variables (indicators) the authors created a linear regression model. Values of regression 
Table 3. The bankruptcy prediction of the selected health care entities based on the Altman's Z" Score Model

\begin{tabular}{ccc}
\hline \multicolumn{3}{c}{ The Altman's Z' score model } \\
\hline $\begin{array}{c}\text { Number of entity and prediction of the model for } \\
\text { operating enterprises (50 operating entities) }\end{array}$ & $\begin{array}{c}\text { Number of entity and prediction of the model for } \\
\text { bankrupts (20 bankrupts entities) }\end{array}$ \\
\hline 1 C & $26 \mathrm{C}$ & $1 \mathrm{C}$ \\
2 B & $27 \mathrm{~B}$ & $2 \mathrm{~B}$ \\
3 C & $28 \mathrm{~B}$ & $3 \mathrm{~B}$ \\
4 B & $29 \mathrm{C}$ & $4 \mathrm{~B}$ \\
5 B & $30 \mathrm{C}$ & $5 \mathrm{C}$ \\
6 B & $31 \mathrm{C}$ & $6 \mathrm{~B}$ \\
7 B & $32 \mathrm{C}$ & $7 \mathrm{~B}$ \\
8 B & $33 \mathrm{C}$ & $8 \mathrm{C}$ \\
9 C & $34 \mathrm{C}$ & $9 \mathrm{C}$ \\
10 C & $35 \mathrm{~B}$ & $10 \mathrm{~B}$ \\
11 B & $36 \mathrm{C}$ & $11 \mathrm{C}$ \\
12 C & $37 \mathrm{C}$ & $12 \mathrm{~B}$ \\
13 C & $38 \mathrm{C}$ & $13 \mathrm{~B}$ \\
14 B & $39 \mathrm{C}$ & $14 \mathrm{C}$ \\
15 B & $40 \mathrm{C}$ & $15 \mathrm{C}$ \\
16 B & $41 \mathrm{C}$ & $16 \mathrm{C}$ \\
17 B & $42 \mathrm{C}$ & $17 \mathrm{~B}$ \\
18 C & $43 \mathrm{C}$ & $18 \mathrm{~B}$ \\
19 C & $44 \mathrm{C}$ & $19 \mathrm{~B}$ \\
20 C & $45 \mathrm{C}$ & $20 \mathrm{~B}$ \\
21 B & $46 \mathrm{C}$ & \\
22 B & $47 \mathrm{C}$ & \\
23 C & $48 \mathrm{C}$ & \\
24 B & $49 \mathrm{C}$ & \\
25 B & $50 \mathrm{C}$ & \\
Model's accuracy 64\% & \\
\hline B-bankruptcy, C-continuation of the entity's business activity & \\
\hline
\end{tabular}

Table 4. The bankruptcy prediction of the selected health care entities based on the Maczyńska’s Model

\begin{tabular}{|c|c|c|}
\hline \multicolumn{3}{|c|}{ The Mączyńska's model } \\
\hline \multicolumn{2}{|c|}{$\begin{array}{c}\text { Number of entity and prediction of the model for } \\
\text { operating enterprises }\end{array}$} & \multirow{2}{*}{$\begin{array}{l}\text { Number of entity and prediction of the model for } \\
\text { bankrupts }\end{array}$} \\
\hline $1 \mathrm{~B}$ & $26 \mathrm{C}$ & \\
\hline $2 \mathrm{~B}$ & $27 \mathrm{C}$ & $2 \mathrm{~B}$ \\
\hline $3 \mathrm{C}$ & $28 \mathrm{~B}$ & $3 \mathrm{~B}$ \\
\hline $4 \mathrm{~B}$ & $29 \mathrm{~B}$ & $4 \mathrm{~B}$ \\
\hline $5 \mathrm{~B}$ & $30 \mathrm{C}$ & $5 \mathrm{C}$ \\
\hline $6 \mathrm{~B}$ & $31 \mathrm{C}$ & $6 \mathrm{~B}$ \\
\hline $7 \mathrm{~B}$ & $32 \mathrm{~B}$ & $7 \mathrm{~B}$ \\
\hline $8 \mathrm{~B}$ & $33 \mathrm{~B}$ & $8 \mathrm{C}$ \\
\hline $9 \mathrm{~B}$ & $34 \mathrm{C}$ & $9 \mathrm{C}$ \\
\hline $10 \mathrm{~B}$ & $35 \mathrm{~B}$ & $10 \mathrm{~B}$ \\
\hline $11 \mathrm{~B}$ & $36 \mathrm{C}$ & $11 \mathrm{~B}$ \\
\hline $12 \mathrm{C}$ & $37 \mathrm{C}$ & $12 \mathrm{~B}$ \\
\hline $13 \mathrm{~B}$ & $38 \mathrm{C}$ & $13 \mathrm{~B}$ \\
\hline $14 \mathrm{~B}$ & $39 \mathrm{C}$ & $14 \mathrm{~B}$ \\
\hline $15 \mathrm{~B}$ & $40 \mathrm{C}$ & $15 \mathrm{C}$ \\
\hline $16 \mathrm{~B}$ & $41 \mathrm{C}$ & $16 \mathrm{C}$ \\
\hline $17 \mathrm{~B}$ & $42 \mathrm{C}$ & $17 \mathrm{~B}$ \\
\hline $18 \mathrm{C}$ & $43 \mathrm{C}$ & $18 \mathrm{~B}$ \\
\hline $19 \mathrm{~B}$ & $44 \mathrm{~B}$ & $19 \mathrm{C}$ \\
\hline $20 \mathrm{C}$ & $45 \mathrm{C}$ & $20 \mathrm{~B}$ \\
\hline $21 \mathrm{~B}$ & $46 \mathrm{C}$ & Model's accuracy $65 \%$ \\
\hline $22 \mathrm{~B}$ & $47 \mathrm{C}$ & \\
\hline $23 \mathrm{C}$ & $48 \mathrm{C}$ & \\
\hline $24 \mathrm{~B}$ & $49 \mathrm{C}$ & \\
\hline $25 \mathrm{C}$ & $50 \mathrm{C}$ & \\
\hline \multicolumn{2}{|c|}{ Model's accuracy } & \\
\hline
\end{tabular}


coefficients for particular variables and their statistical significance were estimated using the $t$ test (Table 5).

Observation of the $t$ test statistics of the obtained coefficients indicates that not all of them are statistically significant (the critical value of statistics for the indicated number of observations and variables is 2.002 for $\alpha=0.05$ ). Therefore, in the next step of the research, it was decided to reject the variable with the lowest value of the $t$ test statistic. It was variable $\mathrm{X}_{19}$. Continuing the abovedescribed procedure in the following steps the following variables were rejected successively (in this order): $\mathrm{X}_{8}, \mathrm{X}_{7}, \mathrm{X}_{12}$, $\mathrm{X}_{13}, \mathrm{X}_{9}, \mathrm{X}_{14}$.

Finally the following variables were chosen to predict the bankruptcy for the studied health care entities: $\mathrm{X}_{1}, \mathrm{X}_{2}, \mathrm{X}_{5}, \mathrm{X}_{6}$, $\mathrm{X}_{10}$ and $\mathrm{X}_{18}$. The regression coefficients and their $t$ test value for the chosen variables are presented in the Table 6 .

Coefficient of determination $\left(R^{2}\right)$ of the model constructed by the authors (containing the above mentioned 6 variables) is near to $75 \%$. The final form of the discriminatory function of the developed regression is as follows in formula (3):

$$
\begin{aligned}
& D f=0.0445 X_{1}-0.9236 X_{2}+0.0261 X_{5} \\
& -1.0952 X_{6}+0.1165 X_{10}+1.1292 X_{18}
\end{aligned}
$$

where:

$\mathrm{X}_{1}$-Current ratio (CR)

Current assets/Current liabilities

$\mathrm{X}_{2}$-Working capital ratio

Working capital/total assets

$\mathrm{X}_{5}$-Debt to equity ratio $(\mathrm{D} / \mathrm{E})$

Total liabilities/Equity

$\mathrm{X}_{6}$-Current liabilities ratio

Table 5. Regression coefficients and their t test value for created financial distress model

\begin{tabular}{ccc}
\hline Explanatory variable & Regression coefficient & T test value \\
\hline$X_{1}$ & 0.04302 & 1.880227 \\
$X_{2}$ & -1.01711 & -2.94669 \\
$X_{5}$ & 0.02457 & 3.321152 \\
$X_{6}$ & -1.36771 & -3.44819 \\
$X_{7}$ & -0.03924 & -0.89997 \\
$X_{8}$ & 0.00001 & 0.83978 \\
$X_{9}$ & 0.00002 & 1.708591 \\
$X_{10}$ & 0.18836 & 3.828542 \\
$X_{12}$ & 0.35501 & 1.788571 \\
$X_{13}$ & 0.53656 & 1.897946 \\
$X_{14}$ & -0.24213 & -2.22065 \\
$X_{18}$ & 1.00019 & 4.459266 \\
$X_{19}$ & 0.00030 & 0.420155 \\
\hline
\end{tabular}

Table 6. Regression coefficients and their t test value qualified for the authors' discriminatory model

\begin{tabular}{ccc}
\hline Explanatory variable & Regression coefficient & T test value \\
\hline$X_{1}$ & 0.044535 & 2.45422 \\
$X_{2}$ & -0.92355 & -3.19915 \\
$X_{5}$ & 0.02606 & 3.451953 \\
$X_{6}$ & -1.09515 & -3.79911 \\
$X_{10}$ & 0.116476 & 3.27065 \\
$X_{18}$ & 1.12917 & 6.71569 \\
\hline
\end{tabular}


Current liabilities/Total assets

$\mathrm{X}_{10}$-Total assets turnover (TAT)

Sales revenue/assets average

In the next step a critical value for the model was described. It separates insolvent companies (which may go bankrupt soon) and continue to run a business activity. The values of discriminatory functions of the developed model for the selected 70 companies from the health care sector is presented in Table 7.

Analyzing the obtained results, it was found that the critical value in this model should be 0.5 . It also should be indicated by the assignment of the value of the discriminatory function 1 for operating entities and 0 for the bankrupt. Therefore, the authors propose a division of companies as follows:

- I group "L"- value of the discriminatory function is $>0.5$. The entity is at low risk of bankruptcy in the near future.

- II group "B"- value of the discriminatory function is $\leq 0.5$. The entity is at a high risk of bankruptcy.

In the following step the authors tested their model on the example of the selected 70 health care enterprises. The proposed 0.5 critical value correctly estimated 55 of 70 companies, and were $78.57 \%$ of the total sample tested. When analyzing only the bankrupt group the prediction is $80 \%$.

\section{DISCUSSION}

The purpose of the paper was to construct a new model for financial distress prediction dedicated for the specificity of medical activity. The next aim was to test it on a researched group of small and medium sized hospitals and compare its results with other well-known bankruptcy prediction models not adjusted to medical activity specialization. Such a procedure is justified by the results of other authors' research (Altman, 2005; Kitowski, 2013).

The results show that the prediction of bankruptcy or other financial problems in small and medium sized medical entities are more accurate (nearly 79\%) using a model dedicated for this specific sector of the state economy. Other, common models do not give such precise results (respectively near to $63 \%$ and 54\%). Thus, it can be concluded that the model adapted to the specifics of medical activity and the group of smaller units results in better quality of prediction. These results are in turn different from the results of Kopiński \& Porębski (2015), who based on other Polish models not dedicated to medical units confirmed their universality.

Although the results of the new model application could be higher, considering the considerable financial instability of the health care sector in Poland, the constantly reoccurring problems with financial liquidity and new investment, is worth emphasizing their special usefulness. It is extremely important in the context of prediction of a nearby bankruptcy that model developed by authors correctly predicts the bankruptcy of an entity from the health care sector in $80 \%$ of cases. Moreover, in the group of operating entities, 11 had a value of discriminatory functions below the critical level. It may suggest that in the coming years they may go bankrupt. Therefore, they should be carefully observed to verify the correct predictive capabilities of the proposed model.

The size of the surveyed enterprises perhaps was also a significant determinant for the results obtained. If, in the studied group of entities, we assume the results of Bem et al. (2019), that the size of the hospital 
Table 7. Value of the discriminatory function for the surveyed entities

\begin{tabular}{|c|c|c|c|c|c|}
\hline \multicolumn{4}{|c|}{$\begin{array}{c}\text { Entity/ } \\
\text { Discriminatory function value }\end{array}$} & \multirow[t]{2}{*}{ Entity } & \multirow[t]{2}{*}{$\begin{array}{l}\text { Discriminatory } \\
\text { function value }\end{array}$} \\
\hline & Opera & tities & & & \\
\hline 1 & $1.098 \mathrm{~L}$ & 26 & $0.738 \mathrm{~L}$ & 1 & $0.480 \mathrm{~B}$ \\
\hline 2 & $0.211 \mathrm{~B}$ & 27 & $0.255 \mathrm{~B}$ & 2 & $0.261 \mathrm{~B}$ \\
\hline 3 & $0.336 \mathrm{~B}$ & 28 & $1.048 \mathrm{~L}$ & 3 & $0.337 \mathrm{~B}$ \\
\hline 4 & $0.259 \mathrm{~B}$ & 29 & $0.519 \mathrm{~L}$ & 4 & $-0.083 \mathrm{~B}$ \\
\hline 5 & $0.211 \mathrm{~B}$ & 30 & $0.520 \mathrm{~L}$ & 5 & $0.397 \mathrm{~B}$ \\
\hline 6 & $0.186 \mathrm{~B}$ & 31 & $0.253 \mathrm{~B}$ & 6 & $0.499 \mathrm{~B}$ \\
\hline 7 & $0.249 \mathrm{~B}$ & 32 & $0.506 \mathrm{~L}$ & 7 & $-0.308 \mathrm{~B}$ \\
\hline 8 & $0.477 \mathrm{~B}$ & 33 & $1.030 \mathrm{~L}$ & 8 & $0.549 \mathrm{~L}$ \\
\hline 9 & $0.578 \mathrm{~L}$ & 34 & $0.239 \mathrm{~B}$ & 9 & $0.328 \mathrm{~B}$ \\
\hline 10 & $0.776 \mathrm{~L}$ & 35 & $0.561 \mathrm{~L}$ & 10 & $0.476 \mathrm{~B}$ \\
\hline 11 & $0.937 \mathrm{~L}$ & 36 & $0.637 \mathrm{~L}$ & 11 & $-0.126 \mathrm{~B}$ \\
\hline 12 & $0.830 \mathrm{~L}$ & 37 & $0.924 \mathrm{~L}$ & 12 & $-0.336 \mathrm{~B}$ \\
\hline 13 & $0.779 \mathrm{~L}$ & 38 & $0.816 \mathrm{~L}$ & 13 & $0.241 B$ \\
\hline 14 & $0.505 \mathrm{~L}$ & 39 & $0.870 \mathrm{~L}$ & 14 & $0.310 \mathrm{~B}$ \\
\hline 15 & $0.702 \mathrm{~L}$ & 40 & $1.339 \mathrm{~L}$ & 15 & $0.467 \mathrm{~B}$ \\
\hline 16 & $0.696 \mathrm{~L}$ & 41 & $1.163 \mathrm{~L}$ & 16 & $0.762 \mathrm{~L}$ \\
\hline 17 & $0.674 \mathrm{~L}$ & 42 & $1.155 \mathrm{~L}$ & 17 & $-0.339 B$ \\
\hline 18 & $0.688 \mathrm{~L}$ & 43 & $1.299 \mathrm{~L}$ & 18 & $0.552 \mathrm{~L}$ \\
\hline 19 & $0.280 \mathrm{~B}$ & 44 & $1.046 \mathrm{~L}$ & 19 & $0.192 \mathrm{~B}$ \\
\hline 20 & $0.754 \mathrm{~L}$ & 45 & $0.865 \mathrm{~L}$ & 20 & $0.714 \mathrm{~L}$ \\
\hline 21 & $1.035 \mathrm{~L}$ & 46 & $0.926 \mathrm{~L}$ & & \\
\hline 22 & $0.530 \mathrm{~L}$ & 47 & $1.291 \mathrm{~L}$ & & \\
\hline 23 & $0.711 \mathrm{~L}$ & 48 & $0.809 \mathrm{~L}$ & & \\
\hline 24 & $0.847 \mathrm{~L}$ & 49 & $1.668 \mathrm{~L}$ & & \\
\hline 25 & $1.284 \mathrm{~L}$ & 50 & $0.892 \mathrm{~L}$ & & \\
\hline
\end{tabular}

is not the main determinant of financial performance. In turn, studies conducted by Langabeer et al. (2018), showed that the smaller the hospital is, the probability of financial distress is higher.

In order to confirm the existence of other phenomena affecting financial instability in the health care sector, the research of other authors may be cited. First of all, strong political and economic dependence, nonfinancial factors located within the system, such as ineffectiveness of management, competition, variable and insufficient financing (Landry et al., 2009).

Despite the above, research indicates that the use of the other two popular models does not accurately predict the bankruptcy of the surveyed entities in the coming years.

It is possible, therefore, to confirm the hypothesis that there is a possibility to create a discriminatory model dedicated to SMEs hospitals, where results are more accurate than using different, not adjusted to health care sector specifics, discriminatory models. Indicating financial instability in the health care sector and the above-mentioned other phenomena, this model may be combined with other tools for assessing the financial standing of healthcare entities (e.g., Siedlecki et al., 2015; Holmes, et al., 2017).

\section{CONCLUSION}

This study focuses on a specific and very important economy sector - health care. The obtained results have a greater prognostic value for this specific branch of the economy as compared to the Altman Z"-score model and the Mączyńska's model. It is a kind of 
justification for undertaking this research.

This study has several limitations. Firstly, the limited accessibility of financial data. There is no single data base in Poland concerning the health care sector. The publication of financial data is significantly limited. This resulted also in the inability to calculate some indicators. The next limitation was a smaller size of the research sample. The model accuracy is nearly $79 \%$ and is still not so high. Although these results are much better than in the compared models. Another limitation is that in health care, for assessing the activity effectiveness, not only financial data is important.

Despite the several mentioned limitations, the presented research contributes to literature by constructing a new discriminatory model that is adjusted to an industry specialization as well to a size of a studied companies (SME sector). The research contributes also to the literature by focusing on comparing different domestic and foreign models for forecasting distress of small and medium sized hospitals, as well as attempts to compare these results with the results obtained using the author's model. It seems also to be a very important tool for the entity financial situation assessment, e.g. in the area of investment, as well as development and attractiveness on the local market.

In addition, importantly, this justifies further research into the discriminatory models in the health care sector. For future research directions it is possible to indicate further testing of the proposed model both in the group of SMEs as well as in other groups of medical entities.

\section{ПРИЛАГОЂАВАЊЕ ДИСКРИМИНАТОРНИХ МОДЕЛА У МАЛИМ И СРЕДЫИМ СУБЈЕКТИМА ЗДРАВСТВЕНЕ ЗАШТИТЕ}

\section{Aleksandra Szewieczek, Bartłomiej Lisicki}

\section{Извод}

Чланак приказује употребу дискриминаторне анализе у малим и средњим болницама. Дискриминаторни модели користе се за процену вероватноће банкрота истраживаних болница. Финансијска криза тестира се с два популарна модела, једним страним („Altman Z”Score Model“) и једним домаћим-пољским („Mączyńska Model“) моделом. Аутори такође конструишу сопствени модел, прилагођен специфичностима медицинске активности. Резултати показују да је ауторски модел много погоднији за мале и средње болнице, јер је стопа предвиђања највећа. Може се указати на то да се у здравству, посебно у малим и средњим болницама, дешавају различите појаве које утичу на финансијске проблеме ових предузећа. Упркос томе, ова студија указује да је предложени модел једно од корисних алата за њихову оцену, посебно у комбинацији са другим финансијским и нефинансијским алатима. Коначно, доказана је хипотеза да је могуће креирати дискриминаторни модел намењен малим и средњим болницама, чији су резултати тачнији од коришћења различитих дискриминаторних модела неприлагођених специфичностима здравственог сектора.

Кључне речи: финансијска криза, дискриминаторна наализа, здравство, менаџмент, рачуноводство, МСП 


\section{References}

Altman, E.I. (2005). An emerging market credit scoring system for corporate bonds. Emerging Markets Review, 6 (4), 311-323.

Altman, E.I. (2013). Predicting Financial Distress of Companies: Revisiting the ZScore and ZETA ${ }^{\circledR}$ Models. in Bell, A.R., Brooks, Ch., \& Prokopczuk, M. (Eds.), Handbook of Research Methods and Applications in Empirical Finance. Edward Elgar Publishing Limited. Cheltenham Glos, UK. 428-456.

Altman, E.I. (2018). A fifty-year retrospective on credit risk models, the Altman Z-score family of models and their applications to financial markets and managerial strategies. Journal of Credit Risk, 14 (4), 1-34.

Altman, E.I., \& Hotchkiss, E. (2005). Corporate Financial Distress and Bankruptcy: Predict and Avoid Bankruptcy, Analyze and Invest in Distressed Debt. 3rd Edition. John Wiley \& Sons. New York, USA.

Altman, E.I., \& Narayan, P. (1997). Business Failure Classification Models: An International Survey. Financial Markets, Institutions \& Instruments, 6 (2), 1-57.

Augurzky, B. \& Schmitz, H. (2010). Is There a Future for Small Hospitals in Germany? Ruhr Economic Papers, 198.

Bankruptcy Law, (2019, February the 28th), Journal of Laws 2019, item 498 as amended.

Baranoff, E.G., Sager T.W., \& Shively T.S. (2000). A semi-parametric stochastic line model as a managerial tool for potential insolvency. Journal of Risk and Insurance, 67 (3), 369-396.

Bazzoli, G.J., \& Cleverley W.O. (1994). Hospital bankruptcies: An exploration of potential causes and consequences. Health
Care Management Review, 19 (3), 41-51.

Bednarski, L. (2007). Financial analysis in the enterprise (in Polish). Polskie Wydawnictwa Ekonomiczne. Warsaw, Poland.

Bem, A., Siedlecki, R., Prędkiewicz, P., Gazzola, P., Ryszawska, B., \& Ucieklak-Jeż, P. (2019). Hospitals' Financial Health in Rural and Urban Areas in Poland: Does It Ensure Sustainability? Sustainability, 11 (7), 1932.

Canbas, S., Cabuk, A., \& Kilic, S.B. (2005). Prediction of commercial bank failure via multivariate statistical analysis of financial structures: the Turkish case. European Journal of Operational Research 166 (2), 528-546.

Holmes, G.M., Kaufman, B.G., \& Pink G.H. (2017). Predicting Financial Distress and Closure in Rural Hospitals. Journal of Rural Health, 33, (3), 239-249.

Horwitz, J.R. (2005). Making Profits and Providing Care: Comparing Non-profit, ForProfit, And Government Hospitals. Health Affairs, 24 (3), 790-801.

Gołębiowski, G., \& Żywno, K. (2008). The Effectiveness of the Discriminant Analysis Models. Study Based on the Selected Polish Companies Quoted on the Warsaw Stock Exchange (in Polish). Contemporary Economics, 2 (3), 31-45.

Grice, J.S., \& Ingram, R.W. (2001). Tests of the Generalizability of Altman's Bankruptcy Prediction Model. Journal of Business Research, 54 (1), 53-61.

Iwanowicz, T. (2018). Empirical Verification of the Mechanical Transferability of the Altman Model to the Conditions of Polish Economy and the Sectoral Universality of Models (in Polish). Zeszyty Teoretyczne Rachunkowości, 96 (152), 63-79.

Juszczyk, S., \& Balina, J. (2009). 
Prediction of insolvency the shipping enterprises as a banking decision tool (in Polish). Zeszyty Naukowe SGGW Ekonomika i Organizacja Gospodarki Żywnościowej, 78, 161-174.

Kaur, D., \& Srivastava, S. (2017). Corporate Debt Restructuring and Firm Performance: A Study of Indian Firms. Serbian Journal of Management, 12 (2), 2712810.

Keasey, K., Pindado, J., \& Rodrigues, L. (2015). The determinants of the costs of financial distress in SMEs. International Small Business Journal, 33 (8), 862-881.

Kitowski, J. (2013). Discriminatory Methods as a Tool for Assessment of Bankruptcy Risk (in Polish). Zarządzanie i Finanse, 4 (3), 197-213.

Kopiński, A., \& Porębski, D. (2015). Verification of the effectiveness evalutation model in the financial analysis of public health care entities (in Polish). Zeszyty Naukowe Uniwersytetu Szczecińskiego, 855, „Finanse, Rynki Finansowe, Ubezpieczenia", 74 (2), 459-469.

Landry, A., Landry, R.J., \& Nowak M.C. (2009). Factors associated with hospital bankruptcies: a political and economic framework. Journal of Healthcare Management, 54 (4), 252-271.

Langabeer, J. (2006). Predicting financial distress in teaching hospitals. Journal of Health Care Finance. 33 (2), 84-92.

Langabeer J.R. (2008). Healthcare Operationas Management; A Quantitative Approach to Business and Logistics. Jones and Bartlett Publishers. Sudbury, MA, USA.

Langabeer, II J.R., Lalani, K.H., Champagne-Langabeer, T., \& Helton, J.R. (2018). Predicting Financial Distress in Acute Care Hospitals. Hospital Topics, 96 (3), 75-79.

Mączyńska, E. (1994). The assessment of the enterprise condintion. Simplified methods (in Polish). Życie gospodarcze, 38, 42-45.

Mączyńska, E., \& Zawadzki M. (2006). Discriminatory models of an enterprise' bankruptcy prediction (in Polish), Ekonomista, 2, 205-235.

Merkevicius, E., Garsva G., \& Girdzijauskas, S. (2006). A Hybrid SOMAltman Model for Bankruptcy Prediction. In: Alexandrov V.N., van Albada G.D., Sloot P.M.A., Dongarra J. (Eds) Computational Science - ICCS 2006. ICCS 2006. Lecture Notes in Computer Science, vol 3994. Springer, Berlin, Heidelberg. 364-371.

Ptak-Chmielewska, A., \& Kuleta, P. (2018). Statistical Models in Enterprises Default Risk Assessment - an Example of Application. Econometrics. Advances in Applied Data Analysis, 22 (1), 94-106.

Rogowski, W. (2008). Dilemmas of using bankruptcy risk assessment models under Polish conditions (in polish). In Mączyńska, E. (Ed.), Bankruptcy of enterprises. Selected institutional aspects. SGH. Warsaw, Poland, 243-252.

Siedlecki, R., Bem, A., Prędkiewicz, P., \& Ucieklak-Jeż P. (2015). Measures of Hospital Financial Condition - Empirical Study. In Bratianu, C., Zbuchea, A., Pînzaru, F., Vatamanescu, E.-M., \& Leon, R.D. (Eds), Proceedings of the Strategica Local versus Global. Tritonic. Bucharest, 666-675.

Stein, R.M. (2007). Benchmarking default prediction models: pitfalls and remedies in model validation. Journal of Risk Model Validation, 1 (1), 77-113.

Sun, J., Li, H., Huang, Q., \& He, K. (2013). Predicting financial distress and corporate failure:

A review from the state-of-the-art definitions, modeling, sampling, and featuring approaches. Knowledge-Based 
Systems, 57 (1), 41-56.

Szewieczek, A. (2015). Management Control System in Selected Public Health Care Entities (in Polish). Zeszyty Teoretyczne Rachunkowości, 82 (138), 141150.

The Ordinance of Minister of Health of April 12, 2017 r. on economic and financial indices required for preparation of the analysis and prognosis of economic and financial standing in independent public health care institutions, Journal of Laws 2017, item. 832.

Tomczak, S. K., \& Radosiński, E. (2017). The effectiveness of discriminant models based on the example of the manufacturing sector. Operation Research and Decision, 27 (3), 81-97.

Wardzińska, K. (2012). The example of using discriminant analysis to estimate the companies financial situation (in Polish). Ekonomia i Zarzadzanie, 4 (3), 197-208. 